\title{
Framing the New Southbound Policy in Western media
}

\author{
Ramkowanie nowej polityki wobec Azji \\ Południowo-Wschodniej i Antypodów \\ w Mediach Zachodnich
}

Robert Rajczyk $^{*}$

\begin{abstract}
The New Southbound Policy (NSP) is the key issue in the economic policy agenda of Tsai Ing-wen, the President of the Republic of China. The aim of the article is to examine through the quantitative analysis the content of Western media as well as a group of Asian media outlets about the NSP in order to depict the NSP's image. Twenty-three websites of newspapers, magazines, radio (Voice of Vietnam) and television (CNA) channels have been under the research process. There are two hundred five research units which were identified as news features concerning the New Southbound Policy. Generally, the idea of New Southbound Policy is simultaneously drawn in the media outlets' content as an economic and political agenda. The NSP was introduced both to reduce the economic dependence from China and to raise Tai-
\end{abstract}

\begin{abstract}
Abstrakt
Nowa polityka wobec Azji PołudniowoWschodniej i Antypodów jest kluczową kwestią w programie politycznym prezydent Republiki Chińskiej Tsai Ing-wen. Celem tego artykułu jest zbadanie poprzez analizę ilościową zawartości światowych i azjatyckich środków masowego przekazu i ich przekazów na temat nowej polityki wobec Azji Południowo-Wschodniej i Antypodów. Proces badawczy obejmował 23 strony internetowe gazet, czasopism, stacji radiowej (Voice of Vietnam) i kanału telewizyjnego (CNA). Zidentyfikowano dwieście osiem jednostek badawczych traktujących o Nowej Polityce, której istotą jest zmniejszenie zależności gospodarczej od Chin kontynentalnych i zwiększenie międzynarodowej obecności Tajwanu w regionie Azji Południowo-Wschodniej i Południowej oraz Antypodów. Wymowa
\end{abstract}

* Institute of Journalism and Media Communication, University of Silesia in Katowice (robert.rajczyk@us.edu.pl);

iD https://orcid.org/0000-0003-2848-4775. 
wan's international visibility in the Southeast and South Asia region. In such media content, Taiwan has usually been shaped in a positive way as a vibrant democracy and responsible member of international community complying with the important global issues, such as the UN Sustainable Development Goal, e.g., the UN Climate Framework Convention. Eventually, the New Southbound Policy is being framed as a positive concept that shapes attractive Taiwan's image.

Key words: New Southbound Policy, Southeast Asia, South Asia, media outlets, Taiwan, Republic of China, R.o.C analizowa-nych treści poświęconych nowej polityce ukazuje Tajwan w pozytywnym kontekście jako rozwiniętą demokrację i odpowiedzialnego członka społeczności międzynarodowej, który angażuje się w problemy globalne, takie jak Cele Zrównoważonego Rozwoju ONZ czy Ramowa Konwencja Klimatyczna ONZ.

Słowa kluczowe: NSP, Tajwan, Republika Chińska, Azja Południowo-Wschodnia

\section{Introduction}

The Republic of China has the diplomatic relations with fourteen states in the world including the Holy See, the only diplomatically in Europe.

Taiwan is the one of the main actors of international affairs both in governmental and non-governmental international organizations due to Taiwan's soft power efforts. The Republic of China is a member of those organizations usually as a Chinese Taipei or Separate Customs Territory of Taiwan, Penghu, Kinmen and Matsu. Taiwan's efforts in international affairs are focused on improving the economic potential and the presence in the international community (Rajczyk, 2016, p. 75). It could be described as a "southward policy" which means "a desire to avoid becoming excessively dependent upon economic ties with the mainland" (Yahuda, 1996, p. 290).

The idea of leveraging Taiwan's economic influence in Southeast and South Asia has been developed by the island's politicians since the 1994 (Jing Bojiun, www.nbr.org, 2018). Gary Klintworth stands for that "Taiwan's 'look south' policy is being actively encouraged by the government in an attempt to lessen Taiwan's growing reliance on Mainland China as a market and investment destination" (Klintworth, 1995, p. 150). The three previous presidents of the Republic of China have focused on expanding the economic influence there so far (Paramitaningrum, \& Herlijanto, 2016, p. 1178). "Under President Tsai Ingwen's New Southbound Policy, Taiwan is also striving to broaden exchanges with the 10 Association of Southeast Asian Nations member states, six South Asian countries, Australia and New Zealand on economic and trade cooperation, talent cultivation, resource sharing and regional links. The long-term goal 
is to create a new type of cooperation based on mutual benefits" (2018 - 2019, Taiwan at a Glance, 2018, p. 34). Having analyzed the NSP's agenda, it is obvious that NSP has also been targeted as a soft power tool. Glaser S. Bonnie, Scott Kennedy, Derek Mitchell, Matthew P. Funaiole suggest that "Tsai is actively promoting a multifaceted strategy that leverages Taiwan's cultural, educational, technological, lagricultural, and economic assets while maintaining stable cross-Strait relations. At the heart of the NSP is a desire to weave Taiwan into a 'people-centered' community of nations that spans the Indo-Pacific region" (Glaser, Kennedy, Mitchell, \& Funaiole, 2018, p. 24). Because of the latter statement Taiwan Scholarship and the Government-sponsored New Southbound Policy Scholarship have been founded to further boost talent exchange.

According to J. Megan Greene, the level of development of Taiwan's knowledge-based economy has been a result of human resources investment: "[...] most important in the emergence of Taiwan's knowledge economy have been the state's heavy investment in human resources development through science education; implementation of multi-tiered strategies to reserve the brain drain; S\&T (science and technology - RR) planning; and construction of R\&D (research and development - RR) institutions" (Greene, 2007, p. 148).

The budget allocated to the NSP projects exceed 7.2 billion NT\$ in 2018 and was divided between three ministries as well as the governmental agency (Glaser et al., 2018, p. 24). These are: Tourism Bureau under the supervision of the Ministry of Transportation and Communications, Ministry of Foreign Affairs, Ministry of Education and Ministry of Economic Affairs. The latter ones obtained three fifths of the entire amount of funds. It defines the executive aspects of NSP's projects.

The NSP has been adopted as a promoting tool along with the implementation of the dedicated projects. The NSP's promotion is being done in two dimensions: institutional and executive. The former aspect concerns departments in the Executive Yuan as well as in the Ministry of Foreign Affairs. These are: Department of Information Services, Department of Information Management and Department of Public Relations in the structure of Executive Yuan, whereas the Ministry of Foreign Affairs runs Department of International Information Services that is responsible for the service for foreign correspondents accredited in Taipei.

As far as the executive dimension is concerned, it has been developed through the content of the institutional websites ${ }^{1}$ and periodicals, such as: Taiwan

1 There is a website dedicated to the New Southbound Policy that has been managed by Ministry of Foreign Affairs: https://nspp.mofa.gov.tw as well as the sub-websites directed to the NSP idea such as: https://newsouthboundpolicy.trade.gov.tw or the tabs in the websites related to the Ministry of Education, Financial Supervisory Commission, Executive Yuan or as newsreels, e.g., of Ministry of Economic Affairs, Ministry of Health and Welfare and its agencies. 
Review, Taiwan Panorama or Taiwan Today. All of them are published by the Ministry of Foreign Affairs' Department of International Information Service and are distributed either through the direct distribution in Taiwan's embassies and Taipei's Representative Offices around the world or via email newsletters for subscribers. Furthermore, the Tourism Bureau of Ministry of Transportation and Communications publishes "Travel in Taiwan" magazine with the dedicated features concerning, for instance, the concept of "Taiwan halal."

Generally, the government remains the main source of information about the New Southbound Policy and its agencies or embassies as well as the Taipei's Representative Offices around the world. The information delivered in such a way is processed by journalists. Both the agenda setting theory and framing reveal the final effect of that process.

\section{Agenda setting and framing}

According to the scholars involved in the research process concerning the agenda setting, there are two dimensions of the agenda setting that could be interpreted that follow the idea of Pamela J. Shoemaker, Tim P. Vos, Stephen D. Reese as a "[...] process of selecting, writing, editing, positioning, scheduling, repeating and otherwise massaging information to become news" (Shoemaker, Vos, \& Reese, 2009, p. 73). This is called by Renita Coleman, Maxwell McCombs, Donald Shaw, David Weaver a "first level" which "[...] focuses on the amount of media coverage an issue or other topic receives, the 'second-level' of agenda setting looks at how the media discuss those issues or other objects of attention, such as public figures. Here the focus is on the attributes or characteristics that describe issues, people or other topics in the news and the tone of those attributes. The general effect is the same: the attributes and tone that the media use in their descriptions are the attributes and tone foremost in the public mind" (Coleman, McCombs, Shaw, \& Weaver, 2009, p. 149).

The agenda setting is also defined as a "process of the mass media presenting certain issues frequently and prominently with the result that large segments of the public come to perceive those issues as more important than others. Simply put, the more coverage an issue receives, the more important it is to people. Since this first simple definition of the phenomenon, agenda setting has expanded from a theory describing the transfer of issue salience from the news media to the public to a broader theory that includes a 'second-level' describing the transfer of attribute salience for those issues and many other 'objects' such as political figures" (Coleman et al., 2009, p. 147). 
The process of presenting the New Southbound Policy issue in Western as well as the regional (Southeast Asia, South Asia) media outlets is considered in this survey. It presents the way of transfer of the Western mass media content about the NSP to the Asian media outlets due to the role of mass media with global coverage as a source of information. The survey examines how the regional/Asian mass media quote the Western elite media concerning the New Southbound Policy or if there is such quoting. Coleman et al. call it intern-media agenda setting (Coleman et al., 2009, p. 147). Daniel Berkowitz points that "[...] when a news organization from a larger sphere covers news in a smaller sphere, that large-scale power might be irrelevant. For example, a national media organization covering news that mainly impacts a small geographic community would not necessarily have much power if the local residents in that area were not part of the media organization's audience. There, the local media organization might turn out to have more in influence in the outcome of an issue or event" (Berkowitz, 2009, p. 105).

Apart from agenda setting, the framing is much more important because of the context it creates to the news features. Framing has been defined as "the way events and issues are organized and made sense of, especially by media, media professionals, and their audiences" (Reese, 2001, p. 7). According to Robert Entman, to frame means "to select some aspects of a perceived reality and make them more salient [...] to promote a particular problem definition, causal interpretation, moral evaluation, and/or treatment recommendation" (Entman, 1993, p. 52). Robert M. Entman, Jörg Matthes and Lynn Pellicano's point of view focuses on the examination of "the selection and salience of certain aspects of an issue by exploring images, stereotypes, metaphors, actors and messages" (Entman, Matthes, Pellicano, 2009, p. 180).

However, James Druckman divides frames into two dimensions: frames in communication and frames in thought (Druckman, 2001). "Frames in communication - often referred to as 'media frame' — focus on what the speaker or news text says; such as how an issue is portrayed by elites, while frames in thought focus on what an individual is thinking; such as the value judgment of an issue" (Entman et al., 2009, p. 181).

According to Druckman's division, the survey contains both types. The first part (division by categories) presents how the NSP is being described by journalists (gatekeepers). Shannon Dunwoody claims that a journalistic frame is a "schema or heuristic, a knowledge structure that is activated by some stimulus and is then employed by a journalist throughout story construction" (Dunwoody, 1992, p. 78). The second part of the survey concerns the "frames in thought." It means the way in which the news features have been seen by the readers and have been interpreted as a positive, neutral or negative attitude toward Taiwan.

The research is based on the Salma Ghanem's definition of agenda setting that states: "[...] is now detailing a second level of effects that examines how 
media coverage affects both what the public thinks about and how the public thinks about" (Ghanem, 1997, p. 3).

\section{Methodology of research}

Edward S. Herman and Noam Chomsky state that "[...] 'selection of topics' is one of the key ways in which the media fulfill their 'societal purpose' [...]" (Herman, \& Chomsky, 1994, p. 298). The following analysis is conducted in the line of that concept. First of all, its examines both the information goal and the amount of news features published in selected categories until September 2019 when the idea of New Southbound Policy had been announced.

The selection is being developed in two dimensions. The former dimension concerns the media with the global coverage, the latter one pertains to the media outlets of the New Southbound Policy area. The research results are to depict the media's attitude to the incumbent Taiwanese President's main policy agenda. The research findings of the global media coverage are linked to the potential of Taiwanese soft power's influence on the global media agenda.

The regional media content analysis comprised the agenda of main newspapers, radio channels or newswire magazines in the area of NSP's implementing. It highlights the political as well as the societal importance of New Southbound Policy issue in the NSP states.

All the research units come from the English language media outlets categorized as global or regional/Asian. The units were selected based on the use of "New Southbound Policy" term on the searched website. The outcome depicts the entire volume of searching results achieved between 18th June and 4th October. All types of news have been taken into the consideration during the research process including commentaries (Nalapat, pakobserver.com, 23.09.2019) or opinions (Hawksley, asia.nikkei.com, 04.10.2019). In all cases, the analyzed content is provided by the English version of websites because of that language's role in the global communication. Furthermore, the English editions of newspapers or news agencies entail and determine the importance of the issue.

There are 208 survey records of research units based on the searching results on the websites of the mass media. ${ }^{2}$ The research units come from the different types of media outlets with the global coverage, such as Reuters, AP, New York Times, euronews, France24 or The Diplomat. The latter website provides content about crucial issues of international relations. Due to that fact it has been taken into consideration. The analysis also concerned the content of media from Japan and Hong Kong, such as Kyodo News, The Asahi Shimbun, Nikkei Asian

\footnotetext{
2 The full list is enclosed in Table 1 below.
} 
Review or South China Morning Post. These media influence the public opinion not only in the region, but on the worldwide level as well.

The other research units - 138 - come from the most influential or the largest mass media in Vietnam, Thailand, India, Malaysia, Pakistan, Singapore and the Philippines. They are regarded as the most influential states considering the NSP idea. Their influence was established on the basis of their economic potential. Seven out of eighteen states included in the NSP are ranked in the annual report on the Best Countries to Invest in 2019 covering 30 states (unews.com, 23.09.2019). These are: Vietnam, Singapore, Malaysia, Indonesia, India, Australia and New Zealand. The latter two countries, such as Australia and New Zealand, do not provide the content about New Southbound Policy to the readers both of newspapers and internet websites. No results were found in Financial Review, ABC News Australia, Sydney Morning Herald and The New Zealand Herald. The reasons of lack the NSP's subject, but not Taiwan's issue at all, might concern the distance between Taiwan and those two states located in the Antipodes of the globe as well as Australia's and New Zealand's memberships in the British Commonwealth of Nations. These two reasons determine the direction of Australia's and New Zealand activities, but there is an economic cooperation between them and the Republic of China. ${ }^{3}$ Based on the above, the following media outlets were selected for the analysis:

- Channel News Asia (CNA) from Singapore as well as The Straits Times;

- The New Straits Times and Bernama (news agency) from Malaysia;

- The Philippine News Agency and Manila Times;

- The India Today and Indian Express;

- Bangkok Post;

- Voice of Vietnam (radio channel's website), Vietnam+ and Saigon Times;

- The Jakarta Post;

- Pakistan Observer.

As far as the methodology is concerned, the research process was divided into a few categories. First of all, the entire collection of searching results (208 research units) was categorized into six issues such as: politics, economy, society, science, culture and agriculture. ${ }^{4}$ The outfit of the categories was introduced into the research based on the New Southbound Policy's fields of cooperation, except for the "politics" genre. Despite the declaration made by the President of the Republic of China about the NSP's economic approach, the political aspect cannot be omitted because of Taiwan's specific status in the international relations. Neither Taiwan's issue in international, especially in regional, relations can be separated from the political aspect because of China's extending

3 There are two Taiwan's trade agreements in Indo-Pacific region with Singapore and New Zealand. The latter one was signed in 2013.

${ }^{4}$ The 'society' category consists for example of health, visa regime, cuisine, migration, people-to-people relations, development assistance and humanitarian aid, education. The crossstraits relation are involved in 'politics' category. 
influence in the Southeast Asia region by the political or economic pressure, nor the Chinese impact on Taiwan's economy can be ignored. 39\% of Taiwanese exports is driven to Mainland China as well as 400 thousand Taiwanese employees work there (straitstimes.com, 2019.09.11). Futhermore, according to Humphrey Hawksley, "Taiwanese companies operating in China account for at least 10\% of country's total exports, according to a study by Citibank, which says that Taiwanese technology companies alone employ 10 million people there" (Hawksley, asia.nikkei.com, 04.10.209).

The agricultural category was also taken into the consideration because of its important role in the NSP's agenda (Glaser, Kennedy, Mitchell, \& Funaiole, 2018, pp. 53 - 57). There is a supplementary project called "Young Agricultural Ambassadors New Southbound Policy Exchange Program" within the NSP's policy (english.president.gov.tw, 2018.10.19).

First, each record was assigned to only one of the six categories. Any multiple choices were not possible. Then the same record was assigned to one of the three attitude's interpretations: positive, neutral and negative. Again, multiple choices in this case were not allowed. The attitude concerns the way in which Taiwan was presented in the research unit. The categorization process does not include the differentiation between types of the news features.

\section{Research findings}

Having analyzed the content of media with global coverage, such as: CNN, RT, Al-Jazeera, DW or BBC World News, there are no pieces of information that cover the New Southbound Policy as either political or economic project. However, some features were found in the Reuters, Associated Press or AFP newswire services. In 15 cases Reuters was the source of information for euronews. com, Bangkok Post, Straits Times and CNA (Channel NewsAsia of Singapore), whereas Agence France Presse (AFP) was the source in 5 cases for South China Morning Post and France24 (france24.com) or Asahi Shimbun. The other news agencies, such as Kyodo News, Press Trust of India or Associated Press (AP), provided only one news item concerning the NSP as a policy agenda for their subscribers, including one piece of information paid by BusinessWire (AP). Nevertheless, the feature about Asian firms shuffling their production around the region as China tariffs' hit was the most frequently shared one. Eventually, the Taiwan Today - Taiwanese MOFA's news service was the source of information for the Manila Times, one of the largest and the most popular newspaper in the Philippines. The list of the research units is shown in the Table 1.

The information category "politics" is the most frequent (almost half of all research units $-46 \%$ ). One third of news items stand for economy (34\%), whereas 
seventeen percent for the society and only three percent for the culture, science or agriculture all together.

As far as the division of attitude's share is concerned through the 208 research units, three fifths of them are positive, whereas almost every fourth is negative. Only ten percent represent the neutral attitude to Taiwan.

The categories of "politics" and "economy" dominate in the research pool and stand for the positive adjustment in 53\%. It means that every second feature of information belongs to one of those two categories. Twelve percent positive pieces of information concern the society's subject.

The other division was made for the regional press and the press with global coverage. The Asian press was selected according to its potential of influence on the public opinion in the Southeast and South Asia region.

Three fifths of the analyzed research units are covered by the regional press: Vietnamese, Japanese, Singaporean, Philippine, Malaysian, Indian and Thai or Hong Kong, whereas $45 \%$ of them contain the category "politics." Although the economic news has similar results, there are about $40 \%$ of all research units involved in the survey's process. Furthermore, the agriculture is associated with the economic issues in this quantitative analysis. Besides every fifth piece of information concerns the society issue and just only few of them belong to the categories: "science" and "culture." Furthermore, about two thirds of research units have a positive attitude toward Taiwanese issues, whereas a quarter of them depict Taiwan in a negative light. Only eleven percent is neutral.

Three fifths of analyzed research units contain a positive attitude, but every fourth is negative, whereas every tenth is neutral. Two main categories: "politics" and "economy" cover over three fourths of pieces of information about Taiwan's New Southbound Policy (38\% each one). Every third research unit comprised in the category called "economy" has positive connotation.

As far as the press with global coverage is concerned, a positive attitude toward Taiwan is represented by three-fourths of features. The category "politics" is the most popular among the research units. Two thirds of research units contain it, whereas every third suits to the category "economy." Only ten percent matches the society's category. About $50 \%$ of the total amount of research units ( $45 \%$ exactly) concerning the category "politics" remain positive in tone. Positive news about the economy stands two times less than about politics. 


\section{Conclusions}

The New Southbound Policy has not been presented in the top worldwide Western media as a scoop. It is rather treated as a regional issue. The news or features are usually devoted to Taiwan's role in the Southeast Asia region as a subject of political and economic relations. The NSP policy has been mentioned in this context with the reference to a specific world's attitude to the 1992 consensus outcome. Such an interpretation puts Taiwan in media outlets' agenda. It confirms Taiwan's status as an independent subject of Southeast Asian states' relations as well as the Republic of China's strong international visibility that are depicted in The Diplomat magazine. Despite Taiwan's official status in international law, its visibility has not been questioned. The Republic of China with its well-developed economy and matured democracy has its own impact mainly on the regional political and economic relations in Southeast and South Asia.

The ranking of Most Influential Countries in the world confirms the purposefulness of New Southbound Policy direction. Twelve states out of 80 countries of the world, classified in that chart, were targeted in the NSP agenda. The Most Influential Countries ranking draws from a global perceptions-based survey and countries are ranked based on the highest scores among more than 11 thousand informed elites in a compilation of five country attributes: leader, connected to the rest of the world, influential culture, politically influential and strong international alliances (usnews.com, 24.09.2019). Diagram 3 draws their economic potential according to the Gross Domestic Product's value. Having considered the population, the NSP's "south direction" is also a proper issue. Indonesian as well as Pakistani populations are around 200 million people each, but the Indian population amounts to 2.6 trillion. The GDP per capita of Singapore, Australia, New Zealand and Malaysia is also the highest in the region (usnews.com, 24.09.2019). It is the second reason of including those states into the New Southbound Policy concept. The development success also confirms the suitable direction of NSP (see more about the development success of Singapore, Malaysia, Indonesia, Thailand, Philipines and Brunei: Somjee \& Somjee, 1995).

According to Tsai Ing-wen's idea of NSP that policy focuses on the economy as the main issue. The analysis of the Southeast Asian media outlets' content proves that. The editors and journalists select the information and create news features that match readers' needs and interests.

As far as the content is concerned, it has been developed under the requirements of the agenda setting. Having analyzed the media outlets' content covering the states included in the NSP, some comments should be made. First of all, Vietnamese media content, for example, concentrates on the issues about agriculture, travelling to Taiwan and economic cooperation. This may be due 
to large Vietnamese economic diaspora in the Republic of China. It is supposed that Vietnamese people are interested in those issues mostly. The content of Singaporean mass media - analyzed in this survey — reveals the focus on the aspect of political relations with Taiwan as well as the NSP role in raising Taiwanese soft power. "The spirit of the New Southbound Policy is upheld through Taiwan's leveraging of its soft power to contribute to regional development. In addition to promoting flagship plans and opening up prospective areas, Taiwan is also gradually working on new cooperation initiatives as well as planning measures in other fields. According to international economic forecasts, New Southbound Policy partner countries will enjoy stable governments and robust economic performance in the foreseeable future, allowing their infrastructure development and markets to thrive. Overall international developments are conducive to promoting the New Southbound Policy. Cooperation between Taiwan and these countries will be more focused and incessantly innovative. Government agencies will devote greater attention to these efforts and work hand-inhand with businesses and other sectors of society to consolidate and better utilize resources to achieve win-win scenarios, thus creating a sense of community throughout the region" (ey.gov.tw, 30.09.2019).

Tourism, health care system as well as the visa regime or medical cooperation are the issues being covered by the Thai press. The Philippine and the Malaysian press focused on utility's aspects of bilateral relations between the countries and Taiwan, whereas Indonesian press provides its readers with economic subjects mainly, e.g., Taiwanese investments in Indonesia. However, the Indian press primarily presents the political aspect of the New Southbound Policy due to India's geopolitical status on the global stage and its aspirations in that matter.

Content of media outlets in the Philippines and Malaysia confirms that idea of strengthening people-to-people relations within the frame of New Southbound Policy was appropriate. Concerning the press content in Japan and Hong Kong and of mass media with global coverage it should be stated that both types are dominated by political analyses in the contexts of NSP as a tool of soft power as well as economic and political rivalry between two superpowers: the USA and China.

The final conclusion states that, generally, the idea of New Southbound Policy is drawn in the content provided by the media outlets as an economic and political agenda simultaneously, which was introduced both to reduce the economic dependence from China and to raise Taiwan's international visibility in the Southeast and South Asia region. In such media content, Taiwan is usually presented in the positive way as a vibrant democracy and a responsible member of international community complying with important global issues, such as UN Sustainable Development Goal, e.g., UN Climate Framework Convention. Eventually, the New Southbound Policy has been framed as a positive concept that shapes Taiwan's attractive image. 
Table 1.

\begin{tabular}{|c|c|c|c|c|c|}
\hline \multirow{2}{*}{ Media } & \multirow{2}{*}{ Title } & \multirow{2}{*}{ Subject } & \multicolumn{3}{|c|}{ Attitude } \\
\hline & & & Positive & Neutral & Negative \\
\hline 1 & 2 & 3 & 4 & 5 & 6 \\
\hline \multirow{3}{*}{$\begin{array}{l}\text { Voice of } \\
\text { Vietnam }\end{array}$} & Smart city groups expand & economy & $\times$ & & \\
\hline & $\begin{array}{l}\text { Taiwan suspends special visa pro- } \\
\text { gram for Vietnamese after disappear- } \\
\text { ing act }\end{array}$ & society & & & $x$ \\
\hline & $\begin{array}{l}\text { Taiwanese youths seek agricultural } \\
\text { opportunities in Vietnam }\end{array}$ & agriculture & $x$ & & \\
\hline \multirow[t]{2}{*}{ Vietnam+ } & $\begin{array}{l}\text { Taiwanese youths seek agricultural } \\
\text { opportunities in Vietnam }\end{array}$ & agriculture & $x$ & & \\
\hline & $\begin{array}{l}\text { China's Taiwan to boost investment } \\
\text { in Vietnam }\end{array}$ & economy & $x$ & & \\
\hline NYTimes & $\begin{array}{l}\text { With Chinese Tourism Down, Taiwan } \\
\text { Looks to Lure Visitors From South- } \\
\text { east Asia }\end{array}$ & economy & $x$ & & \\
\hline \multirow[t]{2}{*}{ CNA } & $\begin{array}{l}\text { Asian firms shuffle production around } \\
\text { the region as China tariffs hit (source: } \\
\text { Reuters) }\end{array}$ & economy & $x$ & & \\
\hline & $\begin{array}{l}\text { How Taiwan is looking to children } \\
\text { of overseas brides to bridge gap } \\
\text { between Taiwan and Southeast Asian } \\
\text { countries (video) }\end{array}$ & society & & $x$ & \\
\hline $\begin{array}{l}\text { The Asahi } \\
\text { Shimbun }\end{array}$ & $\begin{array}{l}\text { Asian firms shuffle production around } \\
\text { the region as China tariffs hit (source: } \\
\text { Reuters) }\end{array}$ & economy & $x$ & & \\
\hline $\begin{array}{l}\text { Associated } \\
\text { Press }\end{array}$ & $\begin{array}{l}\text { Taiwan Sells Food Products at Online } \\
\text { Grocery Site to Malaysia (paid con- } \\
\text { tent from BusinessWire) }\end{array}$ & economy & $x$ & & \\
\hline \multirow[t]{3}{*}{ Kyodo News } & $\begin{array}{l}\text { Taiwan's Tsai slams China for freez- } \\
\text { ing individual tourism to island }\end{array}$ & politics & & & $x$ \\
\hline & $\begin{array}{l}\text { China's bullying erodes gains made } \\
\text { from winning hearts in Taiwan }\end{array}$ & politics & & & $x$ \\
\hline & $\begin{array}{l}\text { Taiwan president ends } 2 \text { nd year with } \\
\text { strong economy, low poll numbers }\end{array}$ & politics & $x$ & & \\
\hline \multirow[t]{4}{*}{ Reuters } & $\begin{array}{l}\text { Taiwan seeks to build soft power with } \\
\text { retooled southbound policy }\end{array}$ & politics & $\times$ & & \\
\hline & $\begin{array}{l}\text { Fitch: Taiwan Banks Face Risks in } \\
\text { New Markets in Southbound Push }\end{array}$ & economy & & $\times$ & \\
\hline & $\begin{array}{l}\text { Taiwan to improve ties with India, } \\
\text { official says, despite Chinese disfa- } \\
\text { vour (source: Reuters) }\end{array}$ & economy & $x$ & & \\
\hline & $\begin{array}{l}\text { BRIEF-Deutsche Bank, Bank of } \\
\text { Taiwan agree partnership }\end{array}$ & economy & $x$ & & \\
\hline
\end{tabular}


cont. table 1

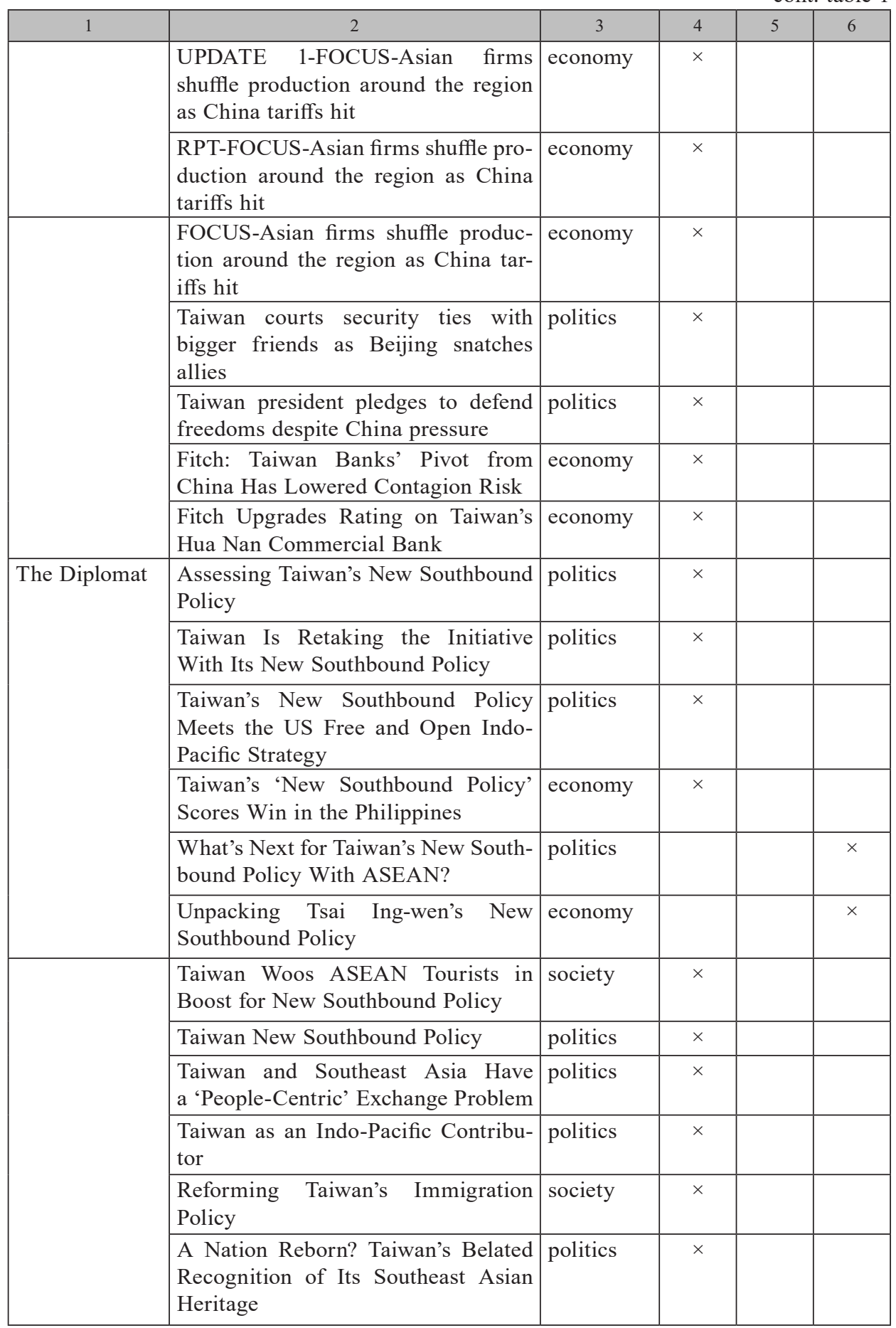


cont. table 1

\begin{tabular}{|c|c|c|c|c|c|}
\hline \multirow[b]{2}{*}{1} & \multirow[b]{2}{*}{2} & \multirow{3}{*}{\begin{tabular}{|c|}
3 \\
society
\end{tabular}} & \multirow{3}{*}{4} & \\
\hline & & & & 5 & 6 \\
\hline & $\begin{array}{l}\text { "Grave Concern" as Cambo- } \\
\text { dia Deports Taiwanese Alleged } \\
\text { Scammers to China Tsai Ing-wen for- } \\
\text { eign policy }\end{array}$ & & & & $\times$ \\
\hline & On Taiwan, the Honeymoon Is Over & politics & & & $\times$ \\
\hline & $\begin{array}{l}\text { The Taipei-Beijing 'Diplomatic } \\
\text { Truce' Crumbles }\end{array}$ & politics & & & $\times$ \\
\hline & $\begin{array}{l}\text { Taiwan's Ruling Party Is Getting } \\
\text { Tough on China Ahead of } 2020\end{array}$ & politics & $x$ & & \\
\hline & $\begin{array}{l}\text { Taiwan's Indo-Pacific Role in the } \\
\text { Spotlight }\end{array}$ & politics & $x$ & & \\
\hline & \begin{tabular}{|lll} 
Taiwan's & Topsy-Turvy & Cross-Strait \\
Politics & & \\
\end{tabular} & politics & & & $\times$ \\
\hline & $\begin{array}{l}\text { Trump, Taiwan, and the 'One China' } \\
\text { Policy }\end{array}$ & politics & $\times$ & & \\
\hline & $\begin{array}{l}\text { Why the US May Lose Taiwan to } \\
\text { Beijing Economically }\end{array}$ & economy & & & $x$ \\
\hline & $\begin{array}{l}\text { It's Official: Taiwan Has a New Presi- } \\
\text { dent }\end{array}$ & politics & $x$ & & \\
\hline & $\begin{array}{l}\text { Where Will US-Taiwan Relations } \\
\text { Under Trump End Up? }\end{array}$ & politics & $x$ & & \\
\hline & $\begin{array}{l}\text { Foreign Laborers and Taiwan's } \\
\text { Evolving Democracy }\end{array}$ & politics & $\times$ & & \\
\hline & Taiwan economic growth & economy & $\times$ & & \\
\hline & Taiwan's 'Little Burma' & society & $\times$ & & \\
\hline & $\begin{array}{l}\text { Heaven and Earth in Chinese Art: } \\
\text { Politics on Display in Australia }\end{array}$ & culture & $x$ & & \\
\hline & $\begin{array}{l}\text { Despite China's Tough Talk, US } \\
\text { Should Move Forward With Taiwan }\end{array}$ & politics & $\times$ & & \\
\hline & Taiwan migrant workers & economy & $\times$ & & \\
\hline & $\begin{array}{l}\text { A Cross-Strait Chill? You Wouldn't } \\
\text { Know It From Taiwan's Economic }\end{array}$ & economy & $x$ & & \\
\hline & $\begin{array}{l}\text { Where Is India on the One China } \\
\text { Policy? }\end{array}$ & politics & $x$ & & \\
\hline & Taiwan Relations Act & politics & $\times$ & & \\
\hline & $\begin{array}{l}\text { KMT Shocks With Its Success in } \\
\text { Taiwan Elections }\end{array}$ & politics & $\times$ & & \\
\hline & $\begin{array}{l}\text { After the Call: Does Taiwan Have a } \\
\text { Plan for the Trump Years? }\end{array}$ & politics & & $\times$ & \\
\hline & $\begin{array}{l}\text { In Taiwan, Exports Stabilize Despite } \\
\text { 16-Month Decline }\end{array}$ & economy & $\times$ & & \\
\hline & $\begin{array}{l}\text { Taiwan's Opposition Must Get Clear } \\
\text { on the Country's Sovereignty }\end{array}$ & politics & $\times$ & & \\
\hline
\end{tabular}


cd. table 1

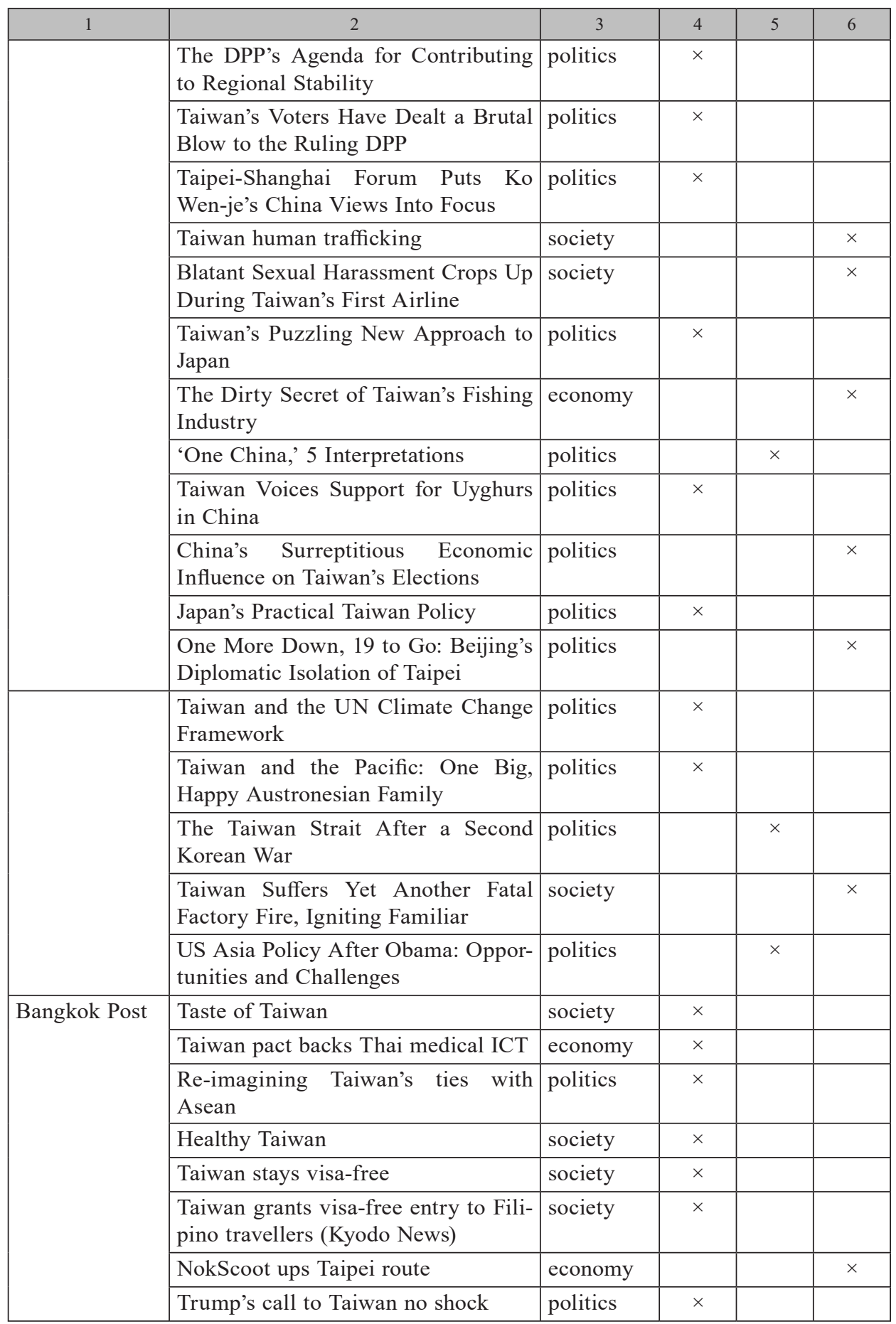


cont. table 1

\begin{tabular}{|c|c|c|c|c|c|}
\hline 1 & 2 & 3 & 4 & 5 & 6 \\
\hline & $\begin{array}{l}\text { Taiwan lawmakers urge Formosa } \\
\text { probe over Vietnam fish deaths (AFP) }\end{array}$ & economy & & & $x$ \\
\hline & $\begin{array}{l}\text { Taiwan diplomacy harder than ever } \\
\text { in US-China tug of war (AFP) }\end{array}$ & politics & $\times$ & & \\
\hline & $\begin{array}{l}\text { China's BRI push marred by trust } \\
\text { deficit }\end{array}$ & economy & $x$ & & \\
\hline & $\begin{array}{l}\text { Taiwan arrests } 7 \text { over Vietnamese } \\
\text { prostitution ring (AFP) }\end{array}$ & society & & & $x$ \\
\hline & $\begin{array}{l}\text { Asian firms shuffle production as } \\
\text { China tariffs hit (source: Reuters) }\end{array}$ & economy & $x$ & & \\
\hline \multirow[t]{12}{*}{$\begin{array}{l}\text { Asia Nikkei } \\
\text { Review }\end{array}$} & $\begin{array}{l}\text { Taiwan — unlikely beneficiary of the } \\
\text { trade war? }\end{array}$ & economy & & $x$ & \\
\hline & $\begin{array}{l}\text { Trade war traps Taiwan between two } \\
\text { superpowers }\end{array}$ & economy & & & $x$ \\
\hline & $\begin{array}{l}\text { Young Taiwanese uproot to Southeast } \\
\text { Asia for pay and prospects }\end{array}$ & economy & & & $x$ \\
\hline & $\begin{array}{l}\text { Taiwan risks getting trumped in trade } \\
\text { war }\end{array}$ & economy & & & $x$ \\
\hline & $\begin{array}{l}\text { Taiwan eyes 'important role' in alter- } \\
\text { native Asian sphere of influence }\end{array}$ & politics & $x$ & & \\
\hline & $\begin{array}{l}\text { Taiwan's Tsai makes limited headway } \\
\text { with 'southbound' turn }\end{array}$ & politics & & & $x$ \\
\hline & $\begin{array}{l}\text { Taiwan is growing impatient with its } \\
\text { president }\end{array}$ & politics & & & $x$ \\
\hline & $\begin{array}{l}\text { Taiwan pledges } \$ 132 \mathrm{~m} \text { to grow } \\
\text { ASEAN and South Asia ties }\end{array}$ & economy & $x$ & & \\
\hline & \begin{tabular}{|l} 
Taiwan companies grapple with \\
China policy shift
\end{tabular} & economy & & & $x$ \\
\hline & $\begin{array}{l}\text { Tsai policy lifts Taiwan stocks tied to } \\
\text { Southeast Asia }\end{array}$ & politics & & $x$ & \\
\hline & $\begin{array}{l}\text { Taiwan's New Southbound Policy is } \\
\text { decreasing its reliance on China }\end{array}$ & politics & $x$ & & \\
\hline & $\begin{array}{l}\text { Loss of Solomon Islands is no signifi- } \\
\text { cant blow to Taiwan }\end{array}$ & politics & $x$ & & \\
\hline \multirow[t]{4}{*}{$\begin{array}{l}\text { The Indian } \\
\text { Express }\end{array}$} & $\begin{array}{l}\text { Raja Mandala: Modi's Taiwan oppor- } \\
\text { tunity }\end{array}$ & politics & $x$ & & \\
\hline & $\begin{array}{l}\text { Consensus growing among nations } \\
\text { on 'Free and Open Indo-Pacific': } \\
\text { Congressman (Press Trust of India) } \\
\end{array}$ & politics & & $x$ & \\
\hline & $\begin{array}{l}\text { Declaring India 'Major Defence Part- } \\
\text { ner' opens door for increased coop- } \\
\text { eration: US official }\end{array}$ & politics & & $x$ & \\
\hline & $\begin{array}{l}\text { Taiwan president Tsai Ing- wen } \\
\text { pledges to defend freedom despite } \\
\text { China pressure }\end{array}$ & politics & $x$ & & \\
\hline
\end{tabular}


cont. table 1

\begin{tabular}{|c|c|c|c|c|c|}
\hline 1 & 2 & 3 & 4 & 5 & 6 \\
\hline \multirow[t]{6}{*}{ India Today } & $\begin{array}{l}\text { Consensus growing among nations } \\
\text { on 'Free and Open Indo-Pacific': } \\
\text { Congressman (Press Trust of India) }\end{array}$ & politics & & $x$ & \\
\hline & MoU 2 & science & & $\times$ & \\
\hline & $\begin{array}{l}\text { Geopolitics wont hamper ties with } \\
\text { India: Taiwan trade body chief }\end{array}$ & economy & $\times$ & & \\
\hline & $\begin{array}{l}\text { India 'playing with fire' by hosting } \\
\text { Taiwan MPs: Chinese media }\end{array}$ & politics & $x$ & & \\
\hline & $\begin{array}{l}\text { Taiwan delegation in India; criticises } \\
\text { One China policy }\end{array}$ & politics & & $x$ & \\
\hline & Reopens FGN 7 & politics & & $\times$ & \\
\hline euronews & $\begin{array}{l}\text { Taiwan to improve ties with India, } \\
\text { official says, despite Chinese disfa- } \\
\text { vour (source: Reuters) }\end{array}$ & economy & $x$ & & \\
\hline \multirow[t]{14}{*}{$\begin{array}{l}\text { South China } \\
\text { Morning Post }\end{array}$} & $\begin{array}{l}\text { Taiwan looks south to find economic } \\
\text { answer to cross- strait bind }\end{array}$ & economy & & $x$ & \\
\hline & $\begin{array}{l}\text { Illegal immigration disrupts Taiwan's } \\
\text { economic shift away from China }\end{array}$ & economy & & & $x$ \\
\hline & $\begin{array}{l}\text { Two reasons Taiwan must come to } \\
\text { terms with China }\end{array}$ & economy & & & $x$ \\
\hline & $\begin{array}{l}\text { Is Beijing planning to take Taiwan } \\
\text { back ... by force? }\end{array}$ & politics & & & $x$ \\
\hline & $\begin{array}{l}\text { Taiwan's wooing of Asean is point- } \\
\text { less. It should just accept China }\end{array}$ & politics & & & $x$ \\
\hline & $\begin{array}{l}\text { Beijing's ban on solo travellers to } \\
\text { Taiwan could cost self-ruled island }\end{array}$ & economy & & & $x$ \\
\hline & $\begin{array}{l}\text { Tourists flock to Taiwan in record } \\
\text { numbers despite drop from mainland } \\
\text { China }\end{array}$ & economy & $x$ & & \\
\hline & $\begin{array}{l}\text { Beijing 'won't allow Taiwan reunifi- } \\
\text { cation to be postponed indefinitely }\end{array}$ & politics & & & $x$ \\
\hline & $\begin{array}{l}\text { Taiwan to hold independence rally in } \\
\text { challenge to Beijing (source: AFP) }\end{array}$ & politics & $\times$ & & \\
\hline & $\begin{array}{l}\text { Harry Potter website bows to fans' } \\
\text { demands that it restore Taiwan to } \\
\text { China in drop-down menu }\end{array}$ & culture & & & $x$ \\
\hline & $\begin{array}{l}\text { First solo travellers, now Beijing cuts } \\
\text { group tours to step up press }\end{array}$ & economy & & & $x$ \\
\hline & $\begin{array}{l}\text { Migrant worker's death at hands of } \\
\text { Taiwan police highlights failing }\end{array}$ & society & & & $x$ \\
\hline & $\begin{array}{l}\text { Taiwan sees opportunity in US- } \\
\text { China trade war }\end{array}$ & economy & $x$ & & \\
\hline & $\begin{array}{l}\text { Taiwan reaches out to Southeast } \\
\text { Asian students to help cut economic } \\
\text { reliance from Beijing }\end{array}$ & society & $x$ & & \\
\hline
\end{tabular}


cont. table 1

\begin{tabular}{|c|c|c|c|c|c|}
\hline 1 & 2 & 3 & 4 & 5 & 6 \\
\hline \multirow[t]{3}{*}{ France24 } & $\begin{array}{l}\text { Taiwan to hold independence rally in } \\
\text { challenge to Beijing (source: AFP) }\end{array}$ & politics & $x$ & & \\
\hline & $\begin{array}{l}\text { Taiwan looks south for Muslim tour- } \\
\text { ist dollars }\end{array}$ & economy & $x$ & & \\
\hline & $\begin{array}{l}\text { Taiwan diplomacy harder than ever } \\
\text { in US-China tug of war }\end{array}$ & politics & $x$ & & \\
\hline \multirow[t]{4}{*}{$\begin{array}{l}\text { The Manila } \\
\text { Times }\end{array}$} & $\begin{array}{|lll|}\begin{array}{l}\text { Taiwan-PH } \\
\text { strengthened }\end{array} & \text { cultural } & \text { relations } \\
\end{array}$ & culture & $x$ & & \\
\hline & Taiwan youth ambassadors in Manila & society & $x$ & & \\
\hline & $\begin{array}{l}\text { The implications of cross- strait con- } \\
\text { flict }\end{array}$ & politics & & $x$ & \\
\hline & $\begin{array}{l}\text { Taipei aims to beef up 'southbound' } \\
\text { youth envoy policy }\end{array}$ & society & & $x$ & \\
\hline Bernama & $\begin{array}{l}\text { Taiwan young ambassadors to visit } \\
\text { Malaysia }\end{array}$ & society & $x$ & & \\
\hline \multirow[t]{7}{*}{$\begin{array}{l}\text { Philipine News } \\
\text { Agency }\end{array}$} & $\begin{array}{l}\text { Taiwan extends visa-free entry for } \\
\text { Pinoys until } 2020\end{array}$ & society & $x$ & & \\
\hline & $\begin{array}{l}\text { TECO now accepting applicants for } \\
\text { Taiwan Fellowship }\end{array}$ & science & $x$ & & \\
\hline & $\begin{array}{l}\text { Taiwan donates P13.5-M aid to } \\
\text { 'Ompong'-hit northern Luzon }\end{array}$ & society & $x$ & & \\
\hline & $\begin{array}{l}\text { New Taipei representative seeks } \\
\text { strong tourism ties with PH }\end{array}$ & economy & $x$ & & \\
\hline & $\begin{array}{l}\text { Taiwan to reassess visa-free entry for } \\
\text { Filipinos July } 2018\end{array}$ & society & $x$ & & \\
\hline & $\begin{array}{l}\text { Taiwan grants visa-free entry for Fili- } \\
\text { pinos starting November }\end{array}$ & society & $x$ & & \\
\hline & \begin{tabular}{|llll} 
More Taiwanese firms keen on \\
expanding in PH
\end{tabular} & economy & $x$ & & \\
\hline \multirow[t]{6}{*}{$\begin{array}{l}\text { The Straits } \\
\text { Times }\end{array}$} & $\begin{array}{l}\text { Warning signals for the 'New South- } \\
\text { bound Policy': The China Post }\end{array}$ & politics & & & $x$ \\
\hline & $\begin{array}{l}\text { Taiwan seeks to build soft power with } \\
\text { retooled southbound policy (source: } \\
\text { Reuters) }\end{array}$ & politics & $x$ & & \\
\hline & $\begin{array}{l}\text { How Taiwan's New Southbound } \\
\text { Policy can succeed: The China Post }\end{array}$ & politics & & & $\times$ \\
\hline & $\begin{array}{l}\text { Taiwan's 'New Southbound Policy' } \\
\text { resembles empty promise: The China } \\
\text { Post }\end{array}$ & politics & & & $x$ \\
\hline & $\begin{array}{l}\text { Taiwan's Southbound policy is } \\
\text { 'purely economics' }\end{array}$ & politics & $x$ & & \\
\hline & $\begin{array}{l}\text { Taiwan's 'pivot south' policy faces } \\
\text { obstacles }\end{array}$ & politics & & & $x$ \\
\hline
\end{tabular}


cont. table 1

\begin{tabular}{|c|c|c|c|c|c|}
\hline 1 & 2 & 3 & 4 & 5 & 6 \\
\hline & $\begin{array}{l}\text { Taiwan's New Southward Policy must } \\
\text { go beyond chasing: The China Post }\end{array}$ & politics & & $x$ & \\
\hline & $\begin{array}{l}\text { Kaohsiung well positioned for new } \\
\text { trade push }\end{array}$ & economy & $x$ & & \\
\hline & $\begin{array}{l}\text { Taiwan appoints trade expert as Sin- } \\
\text { gapore envoy }\end{array}$ & politics & & $x$ & \\
\hline & $\begin{array}{l}\text { Taiwan rebuffs China tourist snub } \\
\text { with record } 2018 \text { arrivals }\end{array}$ & economy & $x$ & & \\
\hline & $\begin{array}{l}\text { Hard for Taiwan to avoid China even } \\
\text { down south }\end{array}$ & politics & & & $x$ \\
\hline & $\begin{array}{l}\text { Taiwan arrests seven over Vietnam } \\
\text { group disappearances }\end{array}$ & society & $x$ & & \\
\hline & $\begin{array}{l}\text { Taiwan's 'pivot south' on track, says } \\
\text { President Tsai Ing-wen }\end{array}$ & politics & $x$ & & \\
\hline & $\begin{array}{l}\text { Taiwan searches for } 152 \text { missing } \\
\text { Vietnamese tourists }\end{array}$ & society & $x$ & & \\
\hline & $\begin{array}{l}\text { Taiwan and Singapore can boost ties } \\
\text { by being "pro- active": Tsai Ing-wen }\end{array}$ & politics & $x$ & & \\
\hline & $\begin{array}{l}\text { Taiwan must tailor approach to each } \\
\text { Asean state: Singapore envoy }\end{array}$ & politics & $x$ & & \\
\hline & $\begin{array}{l}\text { El Salvador deals Taiwan fresh blow } \\
\text { by recognising China }\end{array}$ & politics & & & $\bar{x}$ \\
\hline & $\begin{array}{l}\text { President Tsai's approval rating } \\
\text { drops: The China Post }\end{array}$ & politics & & & $x$ \\
\hline & $\begin{array}{l}\text { Taiwan's US } \$ 172 \text { million boost for } \\
\text { closer trade ties with the region }\end{array}$ & politics & $x$ & & \\
\hline & $\begin{array}{l}\text { Taiwan plans people-centric drive to } \\
\text { wean itself off China }\end{array}$ & society & $x$ & & \\
\hline & $\begin{array}{l}\text { Taiwan's plan to 'pivot south' fraught } \\
\text { with challenges }\end{array}$ & politics & & & $x$ \\
\hline & $\begin{array}{l}\text { Taiwan diplomacy harder than ever } \\
\text { in US-China tug of war }\end{array}$ & politics & $x$ & & \\
\hline & $\begin{array}{l}\text { Taiwan plans visa waiver for Asean } \\
\text { visitors }\end{array}$ & society & $x$ & & \\
\hline & $\begin{array}{l}\text { Taiwan looks to South-east Asia for } \\
\text { Muslim tourist dollars }\end{array}$ & economy & $x$ & & \\
\hline & $\begin{array}{l}\text { Taiwan looks to S-E Asia for Muslim } \\
\text { tourist dollars }\end{array}$ & economy & $x$ & & \\
\hline & $\begin{array}{l}\text { Taiwan makes } \$ 182 \mathrm{~m} \text { 'pivot south' } \\
\text { push }\end{array}$ & economy & $x$ & & \\
\hline & $\begin{array}{l}\text { Tsai vows to defend Taiwan's free- } \\
\text { dom }\end{array}$ & politics & $x$ & & \\
\hline
\end{tabular}


cont. table 1

\begin{tabular}{|c|c|c|c|c|c|}
\hline \multirow[t]{3}{*}{1} & 2 & \multirow{2}{*}{\begin{tabular}{|c|}
3 \\
economy
\end{tabular}} & \multirow{2}{*}{$\begin{array}{l}4 \\
\times\end{array}$} & \multirow[t]{2}{*}{5} & \multirow[t]{2}{*}{6} \\
\hline & $\begin{array}{l}\text { Taichung sets sights on becoming a } \\
\text { boomtown }\end{array}$ & & & & \\
\hline & $\begin{array}{l}\text { Taiwanese tech firms eye online } \\
\text { market in Asean }\end{array}$ & economy & $x$ & & \\
\hline & $\begin{array}{l}\text { Taiwan's current stance on China } \\
\text { could lead to trouble: The China Post }\end{array}$ & politics & & & $x$ \\
\hline & $\begin{array}{l}\text { Taiwan sees more tourists as arrivals } \\
\text { from China drop }\end{array}$ & economy & $x$ & & \\
\hline & $\begin{array}{l}\text { Taiwan courts security ties with } \\
\text { bigger friends as Beijing snatches } \\
\text { allies }\end{array}$ & politics & $x$ & & \\
\hline & $\begin{array}{l}\text { Taiwan shouldn't put all eggs in one } \\
\text { China-shaped basket: The China Post }\end{array}$ & economy & & & $x$ \\
\hline & Grading Tsai's first 100 days in office & politics & & & $\times$ \\
\hline & $\begin{array}{l}\text { Asian firms shuffle production around } \\
\text { the region as China tariffs hit (source: } \\
\text { Reuters) }\end{array}$ & economy & $x$ & & \\
\hline & $\begin{array}{l}\text { Asian firms shuffle production around } \\
\text { region as tariffs on China bite }\end{array}$ & economy & $x$ & & \\
\hline & $\begin{array}{l}\text { Taiwan should avoid baiting China, } \\
\text { say experts }\end{array}$ & politics & & & $\times$ \\
\hline & $\begin{array}{l}\text { Techies wanted for Taiwan's Silicon } \\
\text { Valley }\end{array}$ & economy & $x$ & & \\
\hline & $\begin{array}{l}\text { Taiwan turns up charm to woo } \\
\text { Muslim travelers }\end{array}$ & economy & $x$ & & \\
\hline \multirow[t]{3}{*}{$\begin{array}{l}\text { New Straits } \\
\text { Times }\end{array}$} & $\begin{array}{l}\text { Boosting Asean's stature in pivot to } \\
\text { regional democracy }\end{array}$ & politics & $x$ & & \\
\hline & $\begin{array}{l}\text { Taiwan searches for } 152 \text { missing } \\
\text { Vietnamese tourists }\end{array}$ & society & $x$ & & \\
\hline & $\begin{array}{l}\text { Malaysia still Taiwanese investors' } \\
\text { favorite }\end{array}$ & economy & $x$ & & \\
\hline \multirow[t]{6}{*}{$\begin{array}{l}\text { The Jakarta } \\
\text { Post }\end{array}$} & $\begin{array}{l}\text { Taiwan looks south for Muslim tour- } \\
\text { ist dollars }\end{array}$ & economy & $x$ & & \\
\hline & $\begin{array}{l}\text { RI seeks answers to forced labor alle- } \\
\text { gations }\end{array}$ & society & & & $\times$ \\
\hline & $\begin{array}{l}\text { Indonesia demands answer from } \\
\text { Taiwan over forced labor allegations }\end{array}$ & society & & & $\times$ \\
\hline & $\begin{array}{l}\text { Indonesia to suspend recruitment for } \\
\text { scholarship program in Taiwan }\end{array}$ & society & & & $\times$ \\
\hline & $\begin{array}{l}\text { Taiwan searches for } 152 \text { missing } \\
\text { Vietnamese tourists }\end{array}$ & society & $x$ & & \\
\hline & $\begin{array}{l}\text { Taiwan's advanced medical technol- } \\
\text { ogy gives patients new hope }\end{array}$ & society & $x$ & & \\
\hline
\end{tabular}


cont. table 1

\begin{tabular}{|c|c|c|c|c|c|}
\hline 1 & 2 & 3 & 4 & 5 & 6 \\
\hline & Exploring Taipei's halal tourists sites & economy & $\times$ & & \\
\hline & With new policy, Taiwan turns south & economy & $\times$ & & \\
\hline & $\begin{array}{l}\text { RI set to reap rewards of Taiwan's } \\
\text { NSP }\end{array}$ & politics & $\times$ & & \\
\hline & $\begin{array}{l}\text { Talk of the week: Indonesia, Taiwan } \\
\text { explore potential cooperation }\end{array}$ & politics & $\times$ & & \\
\hline & $\begin{array}{l}\text { Taiwan looks south for Muslim tour- } \\
\text { ist dollars }\end{array}$ & economy & $\times$ & & \\
\hline & $\begin{array}{l}\text { Taiwanese investors seek better } \\
\text { opportunities in Indonesia }\end{array}$ & economy & $\times$ & & \\
\hline & $\begin{array}{l}\text { Indonesia one of Taiwan's important } \\
\text { partners: vice president }\end{array}$ & politics & $\times$ & & \\
\hline & $\begin{array}{l}\text { RI business forum in Taipei aims to } \\
\text { spur investment }\end{array}$ & economy & $\times$ & & \\
\hline & $\begin{array}{l}\text { People-centered orientation key to } \\
\text { New Southbound Policy }\end{array}$ & politics & $\times$ & & \\
\hline & $\begin{array}{l}\text { Taiwan promises increased invest- } \\
\text { ment in Indonesia }\end{array}$ & economy & $\times$ & & \\
\hline & $\begin{array}{l}\text { Kaohsiung to be Taiwan base for } \\
\text { push to Southeast Asia }\end{array}$ & economy & $\times$ & & \\
\hline & $\begin{array}{l}\text { Taiwan seeks more business opportu- } \\
\text { nities with Indonesia }\end{array}$ & economy & $\times$ & & \\
\hline & $\begin{array}{l}\text { Taiwan unveils 'southbound' policy } \\
\text { with beneficial co-op }\end{array}$ & economy & $\times$ & & \\
\hline & $\begin{array}{l}\text { Trial lets Thais, Bruneians come to } \\
\text { Taiwan visa-free }\end{array}$ & society & $\times$ & & \\
\hline & $\begin{array}{l}\text { China, Southeast Asian markets } \\
\text { equally important for Taiwan }\end{array}$ & economy & $\times$ & & \\
\hline & $\begin{array}{l}\text { Taiwan plans people-centric drive to } \\
\text { wean itself off China }\end{array}$ & politics & & $\times$ & \\
\hline Saigon Times & $\begin{array}{l}\text { Tourism ministry asks for measures } \\
\text { to fight illegal overseas travel }\end{array}$ & society & $x$ & & \\
\hline & $\begin{array}{l}\text { Taiwan suspends issuing "Kuan } \\
\text { Hung" visas for Vietnamese }\end{array}$ & society & $\times$ & & \\
\hline $\begin{array}{l}\text { Pakistan } \\
\text { Observer }\end{array}$ & $\begin{array}{l}\text { Trump seeks to stop China becoming } \\
\text { No } 1\end{array}$ & politics & & $\times$ & \\
\hline
\end{tabular}




\section{References}

2018 - 2019 Taiwan at a Glance (2018). Ministry of Foreign Affairs Republic of China, Taipei.

Berkowitz A. D. (2009). Reporters and Their Sources. In The Handbook of Journalism Studies, Karin Wahl-Jorgensen, Thomas Hanitzsch, New York, London, Routledge, pp. $10-15$.

Cole, J. M.: Loss of Solomon Islands is no significant blow to Taiwan, Asia Nikkei Review, 18.09.2019.

Coleman, R., McCombs, M., Shaw, D., \& Weaver, D. (2009). Agenda Setting. In The Handbook of Journalism Studies, Karin Wahl-Jorgensen, Thomas Hanitzsch, New York, London, Routledge, pp. 147-160.

Communication and democracy: exploring the intellectual frontiers in agendasetting theory. Mahwah, New Jersey, London, 1997.

Druckman, J. N. (2001). The implications of framing effects for citizen competence. Political Behavior, 23, pp. 225-256.

Dunwoody, S. (1992). The media and public perceptions of risk: How journalists frame risk stories. In D. W. Bromley, K. Segerson (eds.) The social response to environmental risk: Policy formulation in an age of uncertainty, Boston, pp. $75-100$.

Entman, R. M., Matthes, J., \& Pellicano, L. (2009). Nature, Sources and Effects of News Framing. In The Handbook of Journalism Studies, Karin Wahl-Jorgensen, Thomas Hanitzsch, New York, London, Routledge, p. 17-191.

Entman, R. M. (1993). Framing: Toward clarication of a fractured paradigm. Journal of Communication, 43(4), pp. 51-58.

Glaser S. B., Kennedy S., Mitchell D., \& Funaiole P. M. (2018). The New Southbound Policy. Deepening Taiwan's Regional Integration, Center for Strategic \& International Studies, Rowman \& Littlefield, Lanham.

Ghanem, S. (1997). Filling in the Tapestry: The second Level of Agenda setting. In McCombs, E. M., Shaw, E., Donald L., \& Weaver, H. D. (eds.): Communication and democracy: exploring the intellectual frontiers in agenda-setting theory. Mahwah, New Jersey, London.

Greene, J. M. (2007). Taiwan's knowledge-based economy: A historical perspective on higher education, manpower planning and economic development. In Ash, R., Greene, J. M. (eds.): Taiwan in the 21st Century. Aspects and limitations of a development model. London, New York: Routledge.

Hawksley, H.: Taiwan's New Southbound Policy is decreasing its reliance on China, Asia Nikkei Review, 04.10.2019.

Herman, E., Chomsky, N. (1994). Manufacturing consent: The political economy of the massmedia. London: Vintage.

Jing Bo-jiun, Taiwan's Regional Strategy in Southeast Asia. Kicking the New Southbound Policy into High Gear, 2018.

Klintworth, G. (1995). New Taiwan, New China. Taiwan's changing role in the AsiaPacific region, New York: St. Martin's Press. 
Nalapat, D. M.: Trump seeks to stop China becoming No 1, Pakistan Observer, 06.09.2019.

Paramitaningrum, Herlijanto J. (2016). Economic Diplomacy, Soft Power, and Taiwan's Relations with Indonesia, Contemporary Chinese Political Economy and Strategic Relations: An International Journal, 2(3), pp. 1173-1194.

Rajczyk, R. (2016). World's impact on the Taiwanese Media System, China Media Research, 12 (3), pp. 74-80.

Reese, S. D. (2001). Prologue - Framing public life: A bridging model for media research. In Reese, S. D., Gandy, O. H., Grant, A. E. (eds.): Framing public life: Perspectives on media and our understanding of the social world. Mahwah, New Jersey, Erlbaum, pp. 7-31.

Shoemaker, J. P., Vos, P. T., Reese, D. S. (2009). Journalists as Gatekeepers. In The Handbook of Journalism Studies, Karin Wahl-Jorgensen, Thomas Hanitzsch, New York, London, Routledge, pp. 73-87.

Somjee H. A., \& Somjee G. (1995). Development Success in Asia Pacific, New York, St. Martin's Press.

Taiwan in the 21st Century. Aspects and limitations of a development model (2007). Robert Ash, J. Megan Greene (eds.). London, New York: Routledge.

The Handbook of Journalism Studies (2009). Karin Wahl-Jorgensen, Thomas Hanitzsch, New York, London, Routledge.

The New Southbound Policy. A Practical Approach Moving Full Steam Ahead, Office of Trade Negotiations, Executive Yuan, https://www.ey.gov.tw/File/AA859AF9A742F16C (30.09.2019).

Yahuda, M. (1996). The international standing of the Republic of China on Taiwan, China Quarterly, (148), pp. 1319-1339.

https://www.nbr.org/publication/taiwans-regional-strategy-in-southeast-asia-kick -ing-the-new-southbound-policy-into-high-gear/ (13.08.2019).

https://english.president.gov.tw/News/5568 (28.07.2019).

https://www.straitstimes.com/asia/east-asia/taiwan-president-tsai-ing-wen-rises -from-the-ashes-with-a-hand-from-hong-kong (23.09.2019).

https://www.usnews.com/news/best-countries/best-invest-in (23.09.2019)

https://www.usnews.com/news/best-countries/best-international-influence (24.09.2019). https://pakobserver.net/?s=New+Southbound+Policy (26.09.2019).

https://www.ey.gov.tw/File/AA859AF9A742F16C (30.09.2019).

https://asia.nikkei.com/Opinion/Taiwan-s-New-Southbound-Policy-is-decreasing-its-reliance-on-China (04.10.2019).

https:/asia.nikkei.com/Opinion/Loss-of-Solomon-Islands-is-no-significant-blow-to-

-Taiwan (18.09.2019).

https://www.bangkokpost.com

https://www.thejakartapost.com

https://www.euronews.com

https://www.france24.com

https://www.reuters.com

https://www.ap.org//m-english.vov.vn

https://en.vietnamplus.vn 
https://www.indiatoday.in

https://www.indianexpress.com

https://www.nytimes.com

https://www.channelnewsasia.com

https://www.asahi.com

https://english.kyodonews.net

https://thediplomat.com

https://asia.nikkei.com

https://www.scmp.com

https://www.manilatimes.net

https://www.bernama.com

https://www.pna.gov.ph

https://www.thestraitstimes.com

https://www.nst.com.my

https://en.thesaigontimes.vn

https://www.taiwanhalal.com

https://nspp.mofa.gov.tw

https://www.fsc.gov.tw

https://www.trade.gov.tw

https://www.mohw.gov.tw

https://www.ey.gov.tw

https://www.moe.gov.tw

https://www.moea.gov.tw

https://www.focustaiwan.tw

https://www.icrt.com.tw

https://taiwantoday.tw

https://www.nbr.org

Robert Rajczyk, PhD in Political Sciences, an Assistant Professor in the Institute of Journalism and Media Communication at the University of Silesia in Katowice. His scientific research concerns Public Diplomacy including Digital Diplomacy, Propaganda and Mass Communication as well as the consitutional systems in Central and Eastern Europe, foremost Kosovo, Moldova, Romania and V4 states. He has been Taiwan Fellowship's visiting scholar in 2015, 2017 and 2019. His research projects there have considered: framing of Taiwan in global media and Taiwan's Public Diplomacy. 